\title{
Settlement-timing hypothesis: a critique
}

\author{
Alastair Grant ${ }^{1}$ \& Phillip Williamson ${ }^{2}$ \\ ${ }^{1}$ Dove Marine Laboratory, Cullercoats, Tyne and Wear NE30 4PZ, United Kingdom \\ ${ }^{2}$ N.E.R.C., Polaris House, North Star Avenue, Swindon, Wiltshire SN2 1EU, United Kingdom
}

\begin{abstract}
Todd \& Doyle's (1981) 'settlement-timing hypothesis' for marine benthic invertebrates requires that both optimal spawning date and optimal settlement date are closely determined by environmental conditions. Evidence is lacking that this is the case in the species examined by them. In the absence of evidence, it is inappropriate to attempt to state general theories.
\end{abstract}

\section{INTRODUCTION}

Todd \& Doyle (1981) consider that one of the greatest inadequacies of Vance's (1973a, b) models 'lies in not accounting for the different egg-to-juvenile periods represented by the basic planktotrophic, lecithotrophic and direct (non-pelagic) strategies'. They formulate what they call a 'settlement-timing hypothesis', arguing that when 2 or more modes of development are optional in energetic terms, selection favours the 'strategy' which best bridges the gap between the optimal times for spawning and for settlement.

The hypothesis is based largely on observations made at Robin Hood's Bay, UK, on the nudibranch Onchidoris bilamellata, which feeds on barnacles, mainly Balanus balanoides. The juveniles of $O$. bilamellata are only $0.5 \mathrm{~mm}$ in size, and Todd \& Doyle assume that they can only prey upon small, newly settled barnacles. Accepting that premise, successful reproduction of the nudibranch requires its peak settlement to be closely matched with that of $B$. balanoides, which they state takes place in April and May. Fecundity is proportional to size in O. bilamellata, so they argue that the peak biomass of adults on the shore in January and February indicates the most advantageous time for spawning. If both of these assertions were true, the optimum egg-juvenile development for this species would be about $13 \mathrm{wk}$.

Todd \& Doyle observed the development of Onchidoris bilamellata eggs at various temperatures, produced Arrhenius plots, then calculated the value of $\mathrm{Q}_{10}$ as 2.34 . They use this to 'correct' developmental periods of $O$. bilamellata and related species with other types of development to ambient seawater temperatures, and conclude that the egg-juvenile develop- ment times corresponding to lecithotrophic, direct and planktotrophic development would be 55, 71, and $108 \mathrm{~d}$ respectively. This leads them to suggest that planktotrophic development is most suitable to bridge the gap between optimal spawning and settling times.

In the sympatric Bryozoa feeding species, Onchidoris muricata and Adalaria proxima, they observed that breeding took place at the same time in February to May, with a peak in mid-March. $O$. muricata has small eggs and planktotrophic larvae, with a planktonic phase estimated at $60 \mathrm{~d}$. A. proxima has relatively large eggs $(180 \mu \mathrm{m})$ which hatch after $49 \mathrm{~d}$ to give lecithotrophic veligers which have a planktonic life of 1 to $2 \mathrm{~d}$. Settlement in O. muricata is somewhat later than in $A$. proxima, because of this difference in development times. They suggest that the optimum spawning time is the same for both species, but speculate that the different modes of development are a result of 'differing optimal times to settle', in this case unrelated to the temporal availability of the food resource. Objections can be raised to Todd \& Doyle's arguments on a number of points.

\section{LENGTH OF DEVELOPMENT}

In their general discussion of different development modes, Todd \& Doyle review data for 30 nudibranch gastropods (mostly European) and conclude that there is a close relation between egg-size and length of embryonic development, and between egg-size and development modes. Since information on the total length of larval development is lacking for most of these species, such an analysis is only of marginal relevance to the settlement-timing hypothesis. 
Nevertheless, one aspect of the 30 -species review that warrants further comment is Todd \& Doyle's use of a common $Q_{10}$ value of 2.34 (their mean value for 4 embryonic stages of Onchidoris bilamellata over the range 4 to $19^{\circ} \mathrm{C}$ ) to 'correct' published values on intracapsular development to $10^{\circ} \mathrm{C}$, and the subsequent application of this $Q_{10}$ value to estimate the planktonic life of $O$. bilamellata larvae at $6^{\circ} \mathrm{C}$ from laboratory measurements at $15^{\circ} \mathrm{C}$, and the total development times of alternative reproductive strategies for this species.

Many studies have shown the doubtful reliability of using $Q_{10}$ values in this way. Thus Dehnel (1955) found that for several species of gastropod mollusc, $Q_{10}$ was by no means constant, but varied with temperature and also between species and populations. Further discussion of temperature compensation phenomena is given by Thorson (1950), Bullock (1955), Scheltema (1968, 1971a, b), Strathmann $(1974,1980)$ and Clarke (1982): such work does not support any simplistic $Q_{10}$ 'correction' for marine invertebrates, with examples cited of development rates being the same at $8^{\circ}$ as at $24^{\circ} \mathrm{C}$, and tropical species of gastropods having longer development times than those of temperate waters.

The following factors are also relevant to Todd \& Doyle's estimates of total larval lifetime for Onchidoris bilamellata: (1) changes in field temperature during the egg-juvenile period - Todd \& Doyle assume a constant sea temperature of $6{ }^{\circ} \mathrm{C}$ from mid-January to early May. (2) considerable variability in the time taken for molluscan larvae to reach metamorphosis under standard laboratory conditions (e.g. Bayne 1965) - thus estimates of mean development time may also need to take account of mortality rates. (3) effect of food quality and quantity on larval development times - an aspect likely to show considerable variability under field conditions.

\section{OPTIMAL SPAWNING AND SETTLEMENT TIMES: THE EVIDENCE}

For the settlement-timing hypothesis to be valid, both the optimal spawning date and the optimal settlement date must be closely determined by environmental conditions. Todd \& Doyle suggest that the peak biomass of adult Onchidoris bilamellata on the shore indicates the optimal spawning time. However, nudibranchs are all semelparous, and die immediately after they reproduce. As this is the case, spawning, whenever it occurs, will be followed by a sharp fall in the abundance of animals on the shore as the animals which have completed breeding die. Thus the drop in adult biomass on the shore from February to March does not indicate that February is the optimal time to spawn, rather it indicates the actual time when most animals are breeding!

Data on spawning periods in Onchidoris bilamellata and data of settlement of Balanus cyprids at various locations are presented in Table 1. Examining first the data on $O$. bilamellata, it is apparent that spawning takes place over a prolonged period in all locations. Even allowing that records of spawning continuing until August (e.g. Bruce et al. 1963) represent the precocious maturity of recently settled animals (see Todd 1979 for a discussion), spawning frequently takes

Table 1. Timing of spawning of Onchidoris bilamellata and settlement of Balanus cyprids at various locations

\begin{tabular}{|c|c|c|}
\hline Location & Onchidoris spawning & Balanus settlement \\
\hline \multicolumn{3}{|l|}{ UK } \\
\hline Robin Hoods' Bay, Yorkshire & Dec to Apr (Todd 1979) & Begins May or Jun (Fig. 1 and Kendall in prep.) \\
\hline St. Andrews & Feb to Apr (Laverack \& Blackler 1974) & $\begin{array}{l}\text { Will be somewhat earlier than at Robin Hood's } \\
\text { Bay (Kendall pers. comm.) }\end{array}$ \\
\hline Isle of Man & $\begin{array}{l}\text { Feb to Apr } 1957 \\
\text { Mar to May } 1956 \text { (Miller 1962) } \\
\text { Jan to Aug (Bruce et al. 1963) }\end{array}$ & $\begin{array}{l}\text { May or Jun, with a few settling in Apr in some } \\
\text { years (Hawkins \& Hartnoll 1982) }\end{array}$ \\
\hline Sandgate, Kent & $\begin{array}{l}\text { Late Dec to Apr, with a few adults still } \\
\text { present in early May (Potts } 1970 \text { ) }\end{array}$ & $\begin{array}{l}\text { No precise data for this area. At Plymouth, } \\
\text { settlement can be in early Mar (Kendall pers. } \\
\text { comm.) }\end{array}$ \\
\hline \multicolumn{3}{|l|}{ Europe } \\
\hline Wimereux, France & $\begin{array}{l}\text { Mass spawnings observed in Jul and Aug } \\
\text { (Thompson 1984) }\end{array}$ & As above \\
\hline Netherlands & $\begin{array}{l}\text { Dec to first half of May. Animals scarce } \\
\text { from early Apr. Feeds on Balanus crenatus } \\
\text { (Swennen 1961) }\end{array}$ & $\begin{array}{l}\text { Settlement of } B \text {. crenatus begins in May and } \\
\text { ends in about the } 3 r d \text { week of Jun, with a second } \\
\text { settlement in late summer (de Wolf } 1973 \text { ) }\end{array}$ \\
\hline
\end{tabular}


place over a period of $4 \mathrm{mo}$. This is true even of Todd's (1979) own data. Adults kept by Todd in the laboratory spawned from January to July. In the field (season 1975-76) more spawn was laid in January than in any other month, but the January output was only $37 \%$ of the total. If spawning takes place over such a long period, it must be presumed that the optimual spawning date is not closely determined by environmental conditions.

Neither is the evidence on Balanus settlement as convincing as one might think from reading Todd \&

Main period of release

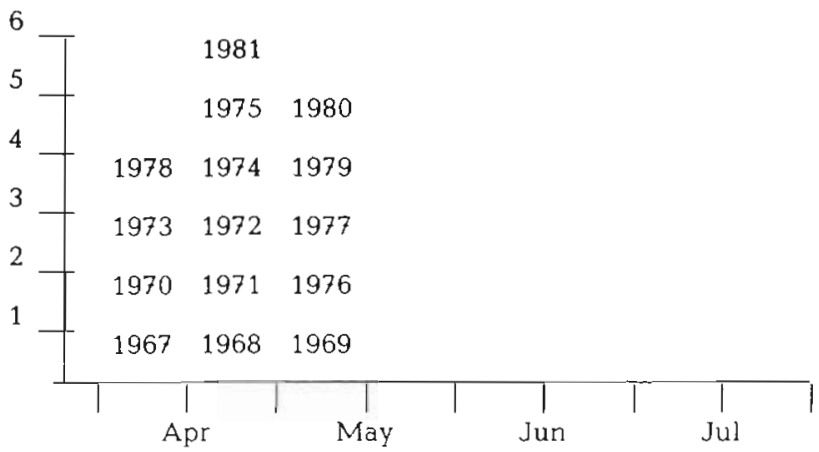

First settlement

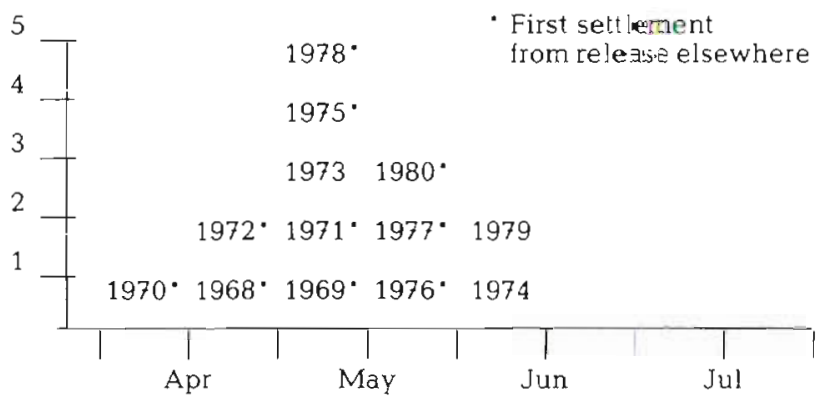

Peak settlement

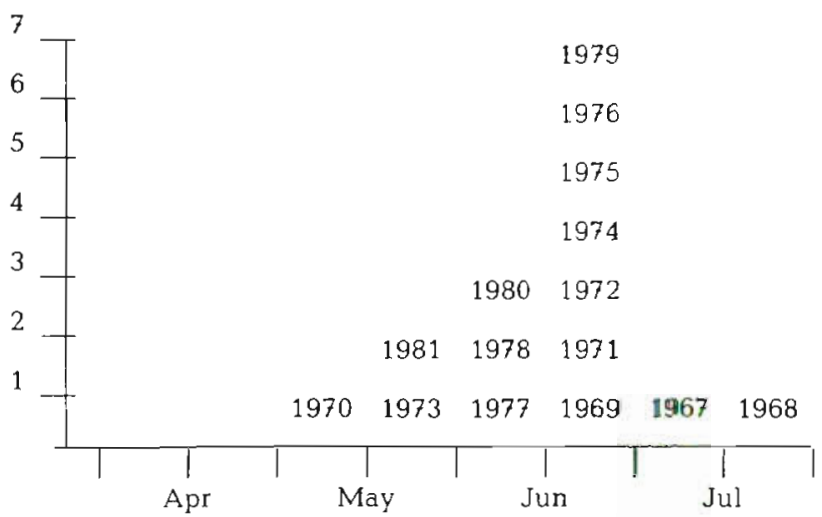

Fig. 1. Balanus balanoides. Timing of larval release and settlement at Robin Hoods Bay, North Yorkshire, 1957-81. Data from Kendall (in prep.). Peak settlement taken as being the maximumum count of metamorphosed cyp itis $\mathrm{m}^{-2}$
Doyle's arguments. They claim that planktotrophic development 'will result in peak settlement amongst Balanus in early May. the time at which $B$. balanoides cyprids are settling in the intertidal', and in the caption to their Fig 4. they estimate the time of Onchidoris bilamellata settlement as 'late April/early May'. However, the time of $B$. balanoides settlement is extremely variable. In Northeast England, release of Balanus nauplii does not usually occur until the middle or end of April (Fig. 1). Cyprids rarely settle in April at Robin Hood's Bay, and sometimes settlement does not begin until June, with the peak count of new recruits being as late as July (Fig. 1; 15 yr mean of maximum metamorph density $=19$ June; $\mathrm{SD}=19 \mathrm{~d}, \mathrm{SE}=5 \mathrm{~d}$; data from Kendall in prep.). If Todd \& Doyle's calculations of settling dates were correct, in most years the nudibranch larvae would metamorphose before any cyprids settle.

Balanus balanoides settlement in the United Kingdom is earliest in the Southwest, then becomes later as one moves up the west coast, round Scotland and into Northeast England. If Onchidoris bilamellata settlement is timed to coincide with this, one would expect its breeding season to show a similar trend. This is not apparent from the data presented in Table 1. In the Isle of Man, where B. balanoides settlement takes place in May or June (Hawkins \& Eartnoll 1982) and Miller (1962) found that $O$. bilamellata bred from March to May, it seems that some $O$. bilamellata will settle at the time which Todd \& Doyle's hypothesis demands, although here at least some $O$. bilamellata may breed as early as January (Bruce et al. 1963), so again some larvae would seem to be in danger of settling too early. In the Netherlands, where its principal food is $B$. crenatus, $O$. bilamellata spawns from December to May, although adults are rare from early April (Swennen 1961). Here, B. crenatus settlement begins in May, and ends by about the third week in June, with a second settlement occurring in late summer (de Wolf 1973). Even allowing that larval development takes over 3 mo, most metamorphosing larvae will be on the shore before cyprids begin to settle.

If Onchidoris bilamellata larvae were able to delay their metamorphosis until Balanus cyprids or young metamorphs were encountered, such differences may not be of critical importance. However, Todd \& Doyle found that adult barnacles (of several species) were effective in stimulating $O$. brlamellata metamorphosis and settlement. This leaves 2 possibilities open. It may be that $O$. bilamellata juveniles can subsist on the shore for some time before B. balanoides cyprids and young metamorphs are available, perhaps by eating microalgae. Alternatively, if $O$. bilamellata juveniles are dependent on young barnacles for food, of uncertain temporal availability, spawning dates must be 
spread over a long period of time in order to ensure some reproductive success.

\section{CONCLUSIONS}

There is little evidence that the optimal spawning time in Onchidoris bilamellata is closely determined by environmental conditions. The evidence that settling time is similarly determined is less compelling than Todd \& Doyle suggest. In the absence of either one of these, the settlement-timing hypothesis fails. It may be that metamorphosed juveniles only survive if their settlement coincides with barnacle settlement, but the date upon which this commences is very variable. The extended spawning season would then be a response to the unpredictability of barnacle settlement.

Todd \& Doyle suggest that the data on the 2 bryozoan-feeding species indicate different optimal settling times. Equally, one could conclude that the settling time is a matter of complete indifference to these species, and the animals simply breed at the time which is optimal, use the form of development which is best for reasons such as dispersal or food availability in the plankton, and the settlement date is then the more or less accidental result. Even if settlement date were important for Onchidoris bilamellata, this is no reason for assuming that it is important for all species of nudibranchs, or indeed all species of invertebrates. The only convincing evidence for species in which both spawning date and the time at which juveniles become free-living in the benthos are constrained to particular times comes from the Antarctic (Clarke 1982). Elsewhere, the settlement-timing hypothesis remains non-proven.

Acknowledgements. We are grateful to Mike Kendall, Paul Tyler and an anonymous referee for helpful comments on various drafts of this work, to the first for giving access to unpublished data, and to Chris Todd for useful discussions. Financial support of NERC and SERC to AG and of NERC to PW, previously through the Rocky Shore Biological Surveillance Programme, is gratefully acknowledged. Such support does not formally involve NERC endorsement of the views expressed.

\section{LITERATURE CITED}

Bayne, B. L. (1965). Growth and the delay of metamorphosis of the larvae of Mytilus edulis (L.). Ophelia 2: 1-47

Bruce, J. R., Colman, J. S., Jones, N. S. (ed.) (1963). Marine fauna of the Isle of Man and its surrounding seas, 2 nd ed. Liverpool University Press, Liverpool

Bullock, T. H. (1955). Compensation for temperature in the metabolism and activity of poikilotherms. Biol. Rev. 30: 311-342

Clarke, A. (1982). Temperature and embryonic development in polar marine inverlebrates. Int. J. Invert. Reprod. 5: 71-82

Dehnel, P. A. (1955). Rates of growth of gastropods as a function of latitude. Fhysiol. Zool. 28: 115-144

de Wolf, P. (1973). Ecological observations on the mechanism of dispersal of barnacle larvae during planktonic life and settling. Neth. J. Seat Res. 6: 1-129

Hawkins, S. J., Hartnoll, R. G. (1982). Settlement patterns in Semibalanus balanoides in the Isle of Man (1977-1981). J. exp. mar. Biol. Ecol. 62: 271-283

Laverack, M. S., Blackler. M. (ed.) (1974). Fauna and flora of St. Andrews Bay. Scattish Academic Press

Miller, M. C. (1962). Annual cycles of some manx nudibranchs, with a discussion of the problem of migration. J. Anim. Ecol. 31: 545-569

Potts, G. W. (1970). The ecology of Onchidoris fusca (Nudibranchia). J. mar. biol. Ass. U.K. 50: 269-292

Scheltema, R. S. (1968). Dispersal of larvae by equatorial currents. Nature, Lond. 217: 1159-1162

Scheltema, R. S. (1971a). The dispersal of the larvae of shoal water benthic invertebrate species over long distances by ocean currents. In: Crisp, D. J. (ed.) 4th European Marine Biology Symposium. Cambridge University Press, Cambridge, p. 7-28

Scheltema, R. S. (1971b). Larval dispersal as a means of genetic exchange between geographically separated populations of shallow water benthic marine gastropods. Biol. Bull. mar. biol. Lab., Woods Hole 140: 284-322

Strathmann, R. R. (1974) Introduction to function and adaptation in echinoderm larvae. Thalassia jugosl. 10: 321-339

Strathmann, R. R. (1980). Why does a larva swim so long. Paleobiology 6: 373-376

Swennen, C. (1961). Data on distribution, reproduction and ecology of the nudibranchiate molluscs occurring in the Netherlands. Neth. J. Sea Res. 1: 191-240

Thompson, T. E. (1984) Migrations of Onchidoris bilamellata during tidal emersion: a refutation. J. mollusc. Stud. 50: 123

Thorson, G. (1950). Reproductive and larval ecology of marine bottom invertebrates. Biol. Rev. 25: 1-45

Todd, C. D. (1979). The population ecology of Onchidoris bilamellata (L.) (Gastropoda: Nudibranchia). J. exp. mar. Biol. Ecol. 41: 213-255

Todd, C. D. (1981): The ecology of nudibranch molluscs. Oceanogr. mar. Biol \& Rev. 19: 141-234

Todd, C. D., Doyle, R. (1981). Reproductive strategies of marine benthic livertebrates: a settlement-timing hypothesis. Mar. Ecol Prog. Ser. 4: 75-83

Vance, R. R. (1973a). Dn reproductive strategies in marine benthic invertebrates. Am. Nat. 107: 339-352

Vance, R. R. (1973b). More on reproductive strategies in marine benthic invertebrates. Am. Nat. 107: 353-361 